will be given by Field-Marshal Viscount Alanbrooke, will be "Birds of Spain", and this discourse, in an area notable for its wild life, is expected to draw a large audience. Archæologically, Norfolk's records of the historic ages prior to the Roman occupation are of absorbing interest, and of the Roman period itself they are probably unsurpassed in Britain.

Forestry and agriculture are perhaps the two sciences to which most justice can be done, since the Forestry Commission owns many acres in west Norfolk where afforestation is intensively pursued; and in the sphere of agriculture it would be hard to refute Norfolk's claim as the cradle of modern farming methods. From the time of Coke of Norfolk onwards, highly developed farming has been the major industry, and local agricultural experimental stations have made significant contributions to the progress of farming throughout the country.

With these factors in mind, and with the backcloth of a gracious cathedral city, the organizers of the Association's 1961 meeting hope that it will be even more successful than its predecessors in Norwich in 1868 and 1935. Every effort will be made to welcome visitors from outside the area and to ensure that they derive all possible pleasure and benefit from the meeting.
D. D. AldRIDGE

\title{
OBITUARIES
}

\section{Mr. J. Walter Ryde, F.R.S.}

JoHN WALter RYDe died at Marlborough, Wilt. shire, on May 15, after a short illness. He was sixty. three years old. He was born in Brighton on April 15, 1898, the son of Mr. W. W. Ryde, and was educated at St. Paul's School and in France. Plans for him to continue his studies in Germany and then go to the University of Cambridge were interrupted by the First World War. He returned from Berlin to England just before the outbreak of war and entered the City and Guilds Technical College, Finsbury, where he studied under Prof. Sylvanus Thompson and Prof. Charles R. Darling.

Ryde joined the Royal Engineers voluntarily in 1916, at the age of eighteen, on the completion of his course at City and Guilds, and was trained in antiaircraft work in Monmouthshire and on the Norfolk coast before being drafted to France during the last few months of the War. He continued to serve in France until his demobilization in 1919.

Ryde joined the Research Laboratories of the General Electric Company, Ltd,, as a physicist in 1919 , going directly from his war service to the newly established research unit directed by Clifford C. Paterson in the Company's lamp factory at Hammersmith. He was a leading member of the scientific staff of the Laboratories from the start.

In the early days at Hammersmith, and again after the Laboratories had moved to their new premises at Wembley in 1923, the variety of Ryde's research work was indicative of the breadth of interests which was so characteristic of him. They included pure spectroscopy, thermionies and the gaseous electrical discharge. Under his direction the first practical high-pressure mercury vapour lamp was developed-the foundation of a new industry to which he made many subsequent contributions.

His theoretical work on the scattering of light, first applied in the 'twenties to optical diffusing media in glasses, was extended by him during the Second World War to elassic studies of the attenuation and the radar echoes produced by meteorological phenomena at centimetre wave-lengths. (A footnote in this paper includes the following: "The author (J.W.R.) and Mrs. Ryde were responsible for the theory and calculation of the effects caused by liquid and solid particles,__.,.) He was an early worker on crystal valves and quickly recognized the potentialities of germanium as a semiconducting material. Other researches included velocity modulation tubes, luminescent materials and optical projection systems. $\mathrm{He}$ contributed much to various research projects undertaken for the United Kingdom Atomic Energy Authority, and he took part in work on the Fido fogdispersal system. It was typical of Ryde to design, in his leisure hours, a pocket illumination chart for use by the Services. It showed levels of illumination, by day and by night, at various latitudes, and was used extensively in military operations.

Ryde was elected a Fellow of the Royal Society in 1948. He was appointed chief physieist at the G.E.C. Research Laboratories-recently named the Hirst Research Centre-in 1950 and chief scientist in 1953. During these recent years he had overall responsibility for the programmes of pure seientific research of the Centre, and his particular interests lay in the fields of new materials, crystal growing and solid-state physics.

He was a member of the Royal Institution of Great Britain since 1935 and chairman of the Davy Faraday Laboratory of the Institution since 1951. He served on the Board of Managers of the Institution and always took a great interest in its affairs. He was a Fellow of the Institute of Physies and the Physical Society, a Fellow of the Royal Astronomical Society, and a member of the Geological Association, the Wiltshire Archæological Society and the Athenæum.

Ryde married, in 1930, Dorothy Ritehie, daughter of the then chief illuminating engineer of the General Electric Co. There is one son.

The Hirst Research Centre has lost a senior man who earned the admiration and respect not only of his colleagues but also of eminent men both in Great Britain and overseas. He lived his life for science, and his leisure activities were very largely extensions of his life's work. Archæology was a persistent interest -at an early age he learned to read hieroglyphic writing and ancient seripts. $\mathrm{He}$ was a profound student of astronomy, but, in recent years, microscopy became a dominant hobby. $\mathrm{H}_{\theta}$ was particularly interested in diatoms, and his beautifully mounted specimens are evidence of the elegant experimental skill which he retained to the end.

His memory was prodigious and visual. He never forgot the details of work which he had done and could sketch from memory some experimental arrangement or the detailed shape of a specimen long afterwards. Such a memory, supplemented with the many carefully prepared and indexed note-books which he compiled throughout his working life, made Ryde a powerful authority indeed in the world of seience. 
In all his work he displayed great ability and unfailing perseverance, together with brilliant insight and inspiration. His colleagues will always remember his patient readiness to discuss and assess the problems of the day and his helpful elucidation of critical experiments, often elegant in their simplicity, which he designed to solve them.

O. W. HuMphreys

\section{Dr. P. A. Gorer, F.R.S.}

THE unexpected death of Dr. Peter Alfred Gorer on May 11 will be deeply regretted by all who knew him. Born in 1907, he was educated at Charterhouse before taking up medicine at Guy's Hospital. During this period he developed an interest in hibernation, and his earliest papers were on this subject. After qualification, he left Guy's for the Department of Genetics at University College, London, under J. B. S. Haldane. It was here, and later at the Lister Institute, that he first began a lifelong study of the genetic and immunological implications of tumour transplantation. At this time only the genetic basis of tumour transplantation had been established. Gorer proposed that genetically determined antigens present in neoplastic tissues were the immediate arbiters of the fate of such grafts. If the transplant introduced antigens not possessed by the recipient animal, rejection of the graft would follow. Between 1937 and the outbreak of the Second World War, he produced solid evidence in support of this idea. During hostilities he acted as assistant morbid anatomist, and hæmatologist, at Guy's Hospital, and remained afterwards as reader in the Department of Experimental Pathology. Only this year he had been chosen to fill the chair of a newly created Department of Immunology at Guy's Hospital.

On returning to the subject of his researches after the War, he spent several years developing the serological methods necessary before any further progress was possible. The defeat of these technical difficulties enabled him to perform a detailed analysis of the major system of tissue antigens in mice, known as the $H-2$ system. His latest paper on this subject indicated the progress which has been made in mapping the genes which dictate the presence of the $H$-2 antigens.

But Gorer was probably best known for his work on the part played by humoral antibody during the rejection of foreign tissue grafts. $\mathrm{He}$ established that such antibodies were present in the serum of mice within three days of receiving a graft of alien tumour; furthermore, normal tissues such as skin were similarly able to excite the formation of humoral antibodies. The function of these antibodies is still the subject of research, but it is clear from his evidence that humoral antibodies have several effects; which one predominates varies according to the target graft, and to a lesser extent the recipient.

At an early stage Gorer was aware of the probability of antigenic differences between normal and malignant tissues. The occurrence of antigenic loss had been implied by much genetic evidence, and he confirmed this by serological means. Few investigations distinguished clearly between normal tissue antigens possessed by tumour cells, and antigens peculiar to the neoplastic state. In 1956, in collaboration with one of his pupils, D. B. Amos, he discovered the first of a series of antigens specific to mouse lymphatic leukæmia cells. Later work showed that such antigens were detectable in spontaneous as well as induced leukæmias. It is sad indeed that he was unable to start on the important investigation of the significance of these antigens.

One cannot account for the pre-eminent position of Peter Gorer merely as a result of his brilliant researches and thoughtful reviews. $\mathrm{He}$ had great charm and wit, a breadth of interest rarely found, and perhaps the most striking attribute of all was an ability to discuss his own subject dispassionately. It gave great pleasure to his many friends and pupils when he was elected Fellow of the Royal Society in 1960 . We shall greatly miss him.

He leaves a widow, a son and a daughter.

\section{J. R. BATCHELOR}

\section{NEWS and VIEWS}

\section{U.S. National Academy of Sciences : Foreign Asso- ciates}

THE following have been elected foreign associates of the U.S. National Academy of Sciences: Prof. K. E. Bullen, professor of applied mathematics in the University of Sydney; Prof. B. Ephrussi, professor of genetics in the Sorbonne, and director of the Genetics Laboratory of the National Centre for Scientific Research at Gif-sur-Yvette; Dr. W. K. Heisenberg, director of the Max Planck Institute for Physies and Astrophysics, Munich; Prof. V. Prelog, professor of organic chemistry and director of the Laboratory, Federal Institute of Technology, Zurich.

Prof. K. E. Bullen, F.R.S.

Prof. Bullen is a native of New Zealand, born in Auckland in 1906. His interest in seismology was aroused by New Zealand's Hawke's Bay earthquake of 1931 and encouraged by Sir Harold Jeffreys, whom he met the same year, during Bullen's studies in
Cambridge. Together they produced the JeffreysBullen tables of seismic travel times, which have been used since 1940 in preparing the International Seismological Summary. Bullen's pressure-incompressibility hypothesis, issued in 1946, led to the inference that the Earth's inner core is solid (in the sense that it can transmit seismic waves), although surrounded by a fluid outer core; it also led him to construct his Earth model $B$, a widely used mathematical model of the Earth's seismic functions. In addition, Prof. Bullen is the author of several papers on the internal structures of Venus and Mars and on the origin of the Moon.

Prof. B. Ephrussi

Prof. Ephrussi was born in Moscow in 1901. On completing his secondary education there, he went to Paris in 1919 and continued his studies at the Sorbonne, where he received a Rockefeller Foundation fellowship and obtained the D.Sc. degree in 1932. During 1930-34 he undertook investigations in the field of chemical embryology and tissue culture, 